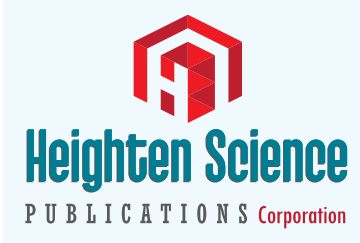

ISSN

2639-9946

\title{
Dietary and Lifestyles assessment among Obese Women in Gaza City, Palestine
}

\author{
Marwan 0 Jalambo1*, Basil Kanoa², Mohammed S Ellulu, Smaher \\ Younis ${ }^{2}$ and Mueen El-Kariri ${ }^{2}$ \\ ${ }^{1}$ Nutrition and Public Health Division, Academic Department, Palestine Technical College, Gaza, \\ Palestine \\ ${ }^{2}$ Ministry of Health, Gaza, Palestine \\ ${ }^{3}$ Clinical Nutrition Specialist, Gaza, Palestine
}

${ }^{*}$ Address for Correspondence: Marwan 0 Jalambo (PhD), Nutrition and Public Health Division, Academic Department, Palestine Technical College, Gaza, Palestine, Tel: +97082531171; Fax: +97082538101; Email: moj_biology@yahoo.com

Submitted: 16 November 2018

Approved: 03 December 2018

Published: 04 December 2018

Copyright: () 2018 Jalambo MO, et al. This is an open access article distributed under the Creative Commons Attribution License, which permits unrestricted use, distribution, and reproduction in any medium, provided the original work is properly cited

Check for updates

\section{Abstract}

Background: The fundamental cause of obesity and overweight is an energy imbalance between calories consumed and calories expended.

Aim: To clarify and figure out food habits and different lifestyle pattern among a sample of Palestinian women attending the nutrition center in the Gaza Strip.

Methods: A cross-sectional study involved 116 women were randomly chosen by purposive census sampling. They aged 25 to 60 years with a diagnosis of obesity. The data collected by interview questionnaire that included social factors, lifestyle habits, and health/disease history.

Results: Age group variable has distributed significantly $(p=0.024),(31.0 \%)$ of morbid obese were $\geq 35$ years group compared to $(13.5 \%)$ of morbid obese amongst the younger group. The higher intakes of legumes (OR: 2.134, $P=0.003$ ), nuts (OR: 3.917, $P=0.019$ ), eggs (OR: 6.840, $P=0.009$ ), fast foods (OR: 4.461, $P=0.005$ ), and soda drinks (OR: $2.230, P=0.004$ ) were the risk factors linked to the increased risk of morbid obesity. Moreover, the higher intakes of legumes (OR: 8.439, $P=0.011$ ), eggs (OR: 6.900, $P=0.041$ ), chips (OR: 5.049, $P=0.012$ ), sugar (OR: 2.068, $P=0.011$ ), and fast foods (OR: $3.029, P=0.025)$ are risk factors of chronic diseases.

Conclusion: The study identified several lifestyle factors and improper dietary habits associated with obesity among women in Gaza city. There is a great need to change these habits to avoid the increased risk of obesity. Gene-environment interaction can explain the high incidence of obesity. A national plan of action to overcome obesity is urgently needed to reduce its economic and health burden.

\section{Introduction}

Obesity is recognized as a multi-factor metabolic change of epidemic proportions [1]. Factors such as inadequate dietary intake, sedentary lifestyle, patterns of physical activity, social and environmental variables were involved in the development of obesity [2]. Other factors like individual susceptibility; determined by unmodified factors such as genetic and family history factors were also considered [2].

Globally, there is a gradual increase in obesity that observed during the last few decades. In fact, some studies have reported that the prevalence of obesity had already reached epidemic proportions in developed and developing countries [3-7].

In Palestine, like many countries, people have lived through rapid globalization that prompted changes in their behaviors and attitudes. Activities that formerly required 
high energy expenditure have been replaced by the ease offered by urbanization and industrial and technological progress, leading, in turn, to lower energy consumption at work, during commuting, and in domestic and leisure activities $[8,9]$.

Obesity is not only considered as a disease in itself, but it also gives rise to and aggravates many others, and is thus known to be a risk factor for certain chronic diseases, in particular being closely associated with metabolic abnormalities like diabetes, cardiovascular diseases, and certain types of cancer [10]. Therefore, this study aimed to figure out food habits and physical activity patterns among Palestinian obese women attending a Nutrition Clinic in the Gaza city.

\section{Materials and Methods}

A cross-sectional study involved 116 women between 25-60 years of age with a diagnosis of obesity during the period from September 2015- October 2016. The enrolment of participants was chosen by non-probability sample using purposive census method for women who attended the Nutrition Clinic in the Gaza city. All women had a stable body weight for at least three months prior to data collection.

Data collected by interview questionnaire, which involved socio-demographic factors, eating habits, health/disease status, and physical activity after signing a written consent form, in which the women's socio-demographic factors included age and marital status (classified to married and unmarried that involved single, widowed, and divorced women). Lifestyle factors in this study involved physical activity pattern, which was evaluated according to the Global Physical Activity Questionnaire (GPAQ) Version-2 that considers the Palestinian specialties. Health/disease history depended on participants self-reporting; disease meant chronic diseases or non-communicable diseases (NCDs) like hypertension and diabetes.

Interview questionnaire involved a section of practicing weight management, Dietary habits, and body mass index (BMI) calculated by using height and weight, which was classified internationally according to World Health Organization, and measured based on the formula [BMI $\left(\mathrm{kg} / \mathrm{m}^{2}\right)=$ Weight $(\mathrm{kg}) /$ Height square $\left.\left(\mathrm{m}^{2}\right)\right]$. BMI was classified according to the obesity status; non-obese [BMI: $\left.<30 \mathrm{~kg} / \mathrm{m}^{2}\right]$ women were excluded from the enrollment of the study. The inclusion criteria involved obese class I [BMI: $\geq 30-<35 \mathrm{~kg} / \mathrm{m}^{2}$ ], obese Class II [BMI: $\geq 35-<40 \mathrm{~kg} / \mathrm{m}^{2}$ ], and morbid obese [BMI: $\geq 40 \mathrm{~kg} / \mathrm{m}^{2}$ ].

The validity of the questionnaire was tested by four experts in the field of nutrition, health, obesity, and chronic diseases from the same community. The accuracy of responses was matched with a participant health records for routine visits. Weight was measured using a commercial scale (Seca Scale, Germany) with an accuracy of $0.01 \mathrm{~kg}$. The subjects were asked to remove their footwear and wear minimal clothes before weighing. Standing body height was measured to the nearest $0.1 \mathrm{~cm}$ by using Holtain Stadiometer with the shoulder in a relaxed position and arms hanging freely and without shoes.

Data were analyzed statistically by using the Statistical Package for Social Sciences version 22.0 software. Descriptive interview session has presented by frequencies and percentages. Chi-square $(\chi 2)$ was used to compare the categorical variables. Binary Logistic Regression was used to estimate the Odds Ratio (OR) for the dietary risk factors. $P$-value of $\leq 0.05$ was considered statistically significant and level of confidence was $95 \%$.

\section{Results}

This study aimed to clarify and figure out food habits and lifestyle pattern among obese women in Gaza city. The recruitment of study participants began in September 2015 and was completed in October 2016. Table 1 describes the baseline characteristics 
of all participated women. The total number was 116 women and 74 (63.8\%) of them were aged $\geq 35$ years. 63 (54.3\%) were married, while the others stated not married who involved single, widowed, and divorced. None of them stated having high physical activity, while 64 (55.2\%) were moderate physically active and the rest were light physical activity.

Regarding the body mass index, 23 (19.8\%) were morbidly obese (BMI $\left.\geq 40 \mathrm{~kg} / \mathrm{m}^{2}\right)$ and $93\left(80.2 \%\right.$ ) were the obese class I and II (ranged from BMI $\geq 30$ to $\mathrm{BMI}<40 \mathrm{~kg} / \mathrm{m}^{2}$ ). In addition, $22(19.0 \%)$ have stated that they have one of the chronic diseases such as hypertension or diabetes type-2, while the rest is free from chronic diseases.

At Table 1 section A, within the interview questionnaire, 116 women were the entire population was involved. The majority 52 (44.8\%) have responded "Not Good" regarding the $1^{\text {st }}$ question "how do you evaluate your current health?". The $2^{\text {nd }}$ question was "what is the main cause to reduce weight? The majority of 66 (56.9\%)

Table 1: Baseline characteristics.

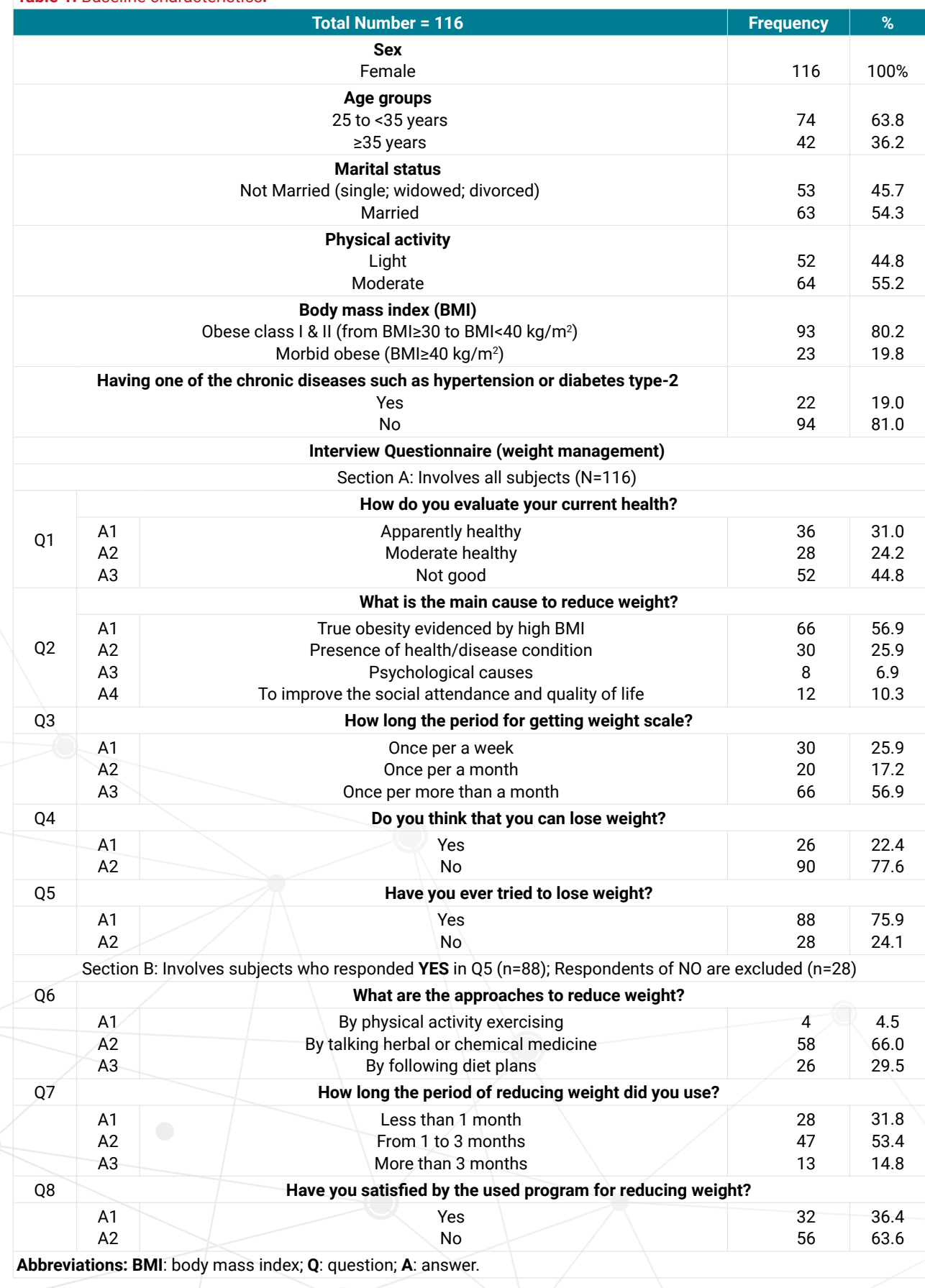


have concerned that they had true obesity evidenced by high BMI. The $3^{\text {rd }}$ question was "how long the period for getting weight scale?", the most frequent answer was "once per more than a month". About $77.6 \%$ of them mentioned that they won't lose a weight in response to the $4^{\text {th }}$ question. Finally, in response to the $5^{\text {th }}$ question, about $75.9 \%$ have used different methods to lose weight in different periods of life.

When the researcher asked the participant regarding trying to lose weight, about three quartiles of them answer they tried to do lose their weight as shown as in table 1. In addition, about two-thirds of women tried to lose their weight was used herbal and chemical medicines without prescription by Dietitians or Physicians. Moreover, the period was used to lose their weight were less than 3 months among the majority of them (85.2\%), and two-thirds of them satisfied their lost weight, and the rest concerned the self-programs that follow it were not satisfied as shows as in table 1.

Table 2 has determined the distribution of subjects' characteristics on two factors; obesity and chronic disease conditions. Three categorical factors have involved; age, marital status, and physical activity. None of the factors have associated significantly with chronic disease. Regarding obesity status, just age group variable has distributed significantly $(p=0.024),(31.0 \%)$ of morbid obese were $\geq 35$ years group compared to $(13.5 \%)$ of morbid obese amongst the younger group.

Prediction of dietary risk factors that contribute to the development of morbid obesity and/or chronic diseases has described in Table 3. Two models have involved by logistic regression; Model-I predicted the risk factors associated with morbid obesity $\left(\mathrm{BMI} \geq 40 \mathrm{~kg} / \mathrm{m}^{2}\right)$, and Model-II predicted the risk factors associated with acquired chronic diseases such as HTN and/or DM.

Model-I in table 3 shows the risk factors associated with morbid obesity, the higher intakes of legumes [OR: 2.134] (95\% CI: 1.901-3.969, $P=0.003$ ),nuts [OR: 3.917] (95\% CI: $1.249-12.289, P=0.019$ ), eggs [OR: 6.840] (95\% CI: 1.601-29.223, $\mathrm{P}=0.009)$, fast foods [OR: 4.461] $(3.057-19.884, \mathrm{P}=0.005)$, and soda drinks [OR: 2.230$]$ (95\% CI: 1.084-8.627, $\mathrm{P}=0.004$ ) were the risk factors linked to the increased risk of morbid obesity. In contrast, lower intakes of meats [OR: 0.085] (95\% CI: 0.011-0.676, $\mathrm{P}=0.020$ ) and fruits [OR: 0.288 ] (95\%CI: 0.084-0.989, $\mathrm{P}=0.048)$, were also the risk factors linked to the increased risk of morbid obesity. By the same way, low physical activity was a risk factor has associated with morbid obesity [OR: 5.183] (95\% CI: 1.731-13.265, $\mathrm{P}=0.002$ ), while the absence of obesity during childhood and absence of family's history of obesity were protective factors.

Model-II in table 3 shows the risk factors associated with obese women who suffer from chronic disease. The higher intakes of legumes [OR: 8.439] (95\% CI: 2.93836.418, $P=0.011$ ), eggs [OR: 6.900] (95\% CI: 1.085-13.862, $\mathrm{P}=0.041$ ), chips [OR: 5.049 ] (2.342-12.700, $\mathrm{P}=0.012$ ), sugar [OR: 2.068] (1.009-4.547, $\mathrm{P}=0.011)$, and fast foods [OR: 3.029] (1.001-12.639, $P=0.025$. In contrast, high intake of nuts, the absence of obesity during childhood and absence of family's history of obesity were protective factors.

\begin{tabular}{|c|c|c|c|c|c|c|c|c|c|c|c|c|}
\hline \multirow{3}{*}{ Factor } & \multicolumn{4}{|c|}{ Obesity } & \multirow{3}{*}{$\mathrm{X}^{2}$ value } & \multirow{3}{*}{$\begin{array}{c}P \\
\text { value }\end{array}$} & \multicolumn{4}{|c|}{ Chronic Disease } & \multirow{3}{*}{$\mathrm{X}^{2}$ value } & \multirow{3}{*}{$\stackrel{P}{\text { value }}$} \\
\hline & \multicolumn{2}{|c|}{$\begin{array}{c}\text { Obese } \\
\text { Class I \& II }\end{array}$} & \multicolumn{2}{|c|}{$\begin{array}{l}\text { Morbid } \\
\text { Obese }\end{array}$} & & & \multicolumn{2}{|c|}{$\begin{array}{c}\text { Not } \\
\text { Diseased }\end{array}$} & \multicolumn{2}{|c|}{ Diseased } & & \\
\hline & $\mathbf{n}$ & $\%$ & $\mathbf{n}$ & $\%$ & & & $\mathbf{n}$ & $\%$ & $\mathbf{n}$ & $\%$ & & \\
\hline Age groups & & & & & & & & & & & & \\
\hline $\begin{aligned} 25 \text { to } & <35 \text { years } \\
& \geq 35 \text { years }\end{aligned}$ & $\begin{array}{l}64 \\
29\end{array}$ & $\begin{array}{l}86.5 \\
69.0\end{array}$ & $\begin{array}{l}10 \\
13\end{array}$ & $\begin{array}{l}13.5 \\
31.0\end{array}$ & 5.126 & $0.024^{\star}$ & $\begin{array}{l}60 \\
34\end{array}$ & $\begin{array}{l}81.1 \\
81.0\end{array}$ & $\begin{array}{c}14 \\
8\end{array}$ & $\begin{array}{l}18.9 \\
19.0\end{array}$ & 0.001 & 0.986 \\
\hline $\begin{array}{c}\text { Marital status } \\
\text { Not married } \\
\text { Married }\end{array}$ & $\begin{array}{l}45 \\
48\end{array}$ & $\begin{array}{l}84.9 \\
76.2\end{array}$ & $\begin{array}{c}8 \\
15\end{array}$ & $\begin{array}{l}15.1 \\
23.8\end{array}$ & 1.375 & 0.241 & $\begin{array}{l}47 \\
47\end{array}$ & $\begin{array}{l}88.7 \\
74.6\end{array}$ & $\begin{array}{c}6 \\
16\end{array}$ & $\begin{array}{l}11.3 \\
25.4\end{array}$ & 3.711 & 0.054 \\
\hline $\begin{array}{c}\text { Physical activity } \\
\text { Light } \\
\text { Moderate }\end{array}$ & $\begin{array}{l}45 \\
48\end{array}$ & $\begin{array}{l}86.5 \\
75.0\end{array}$ & $\begin{array}{c}7 \\
16\end{array}$ & $\begin{array}{l}13.5 \\
25.0\end{array}$ & 2.403 & 0.121 & $\begin{array}{l}42 \\
52\end{array}$ & $\begin{array}{l}80.8 \\
81.2\end{array}$ & $\begin{array}{l}10 \\
12\end{array}$ & $\begin{array}{l}19.2 \\
18.8\end{array}$ & 0.004 & 0.948 \\
\hline
\end{tabular}




\begin{tabular}{|c|c|c|c|c|c|c|c|c|}
\hline \multirow{3}{*}{ Risk factors } & \multicolumn{4}{|c|}{ Model-I } & \multicolumn{4}{|c|}{ Model-II } \\
\hline & \multirow{2}{*}{ OR } & \multicolumn{2}{|c|}{ 95\% C.I. } & \multirow{2}{*}{ P value } & \multirow{2}{*}{ OR } & \multicolumn{2}{|c|}{ 95\% C.I. } & \multirow{2}{*}{ P value } \\
\hline & & lower & upper & & & lower & upper & \\
\hline White Meats & 0.085 & 0.011 & 0.676 & $0.020 *$ & 0.038 & 0.001 & 1.350 & 0.073 \\
\hline Legumes & 2.134 & 1.901 & 3.969 & $0.003^{*}$ & 8.439 & 2.938 & 36.418 & $0.011^{*}$ \\
\hline Vegetables & 0.947 & 0.382 & 2.347 & 0.907 & 0.194 & 0.024 & 1.571 & 0.124 \\
\hline Fruits and juices & 0.288 & 0.084 & 0.989 & $0.048^{*}$ & 2.008 & 0.394 & 10.230 & 0.401 \\
\hline Nuts & 3.917 & 1.249 & 12.289 & $0.019 *$ & 0.036 & 0.002 & 0.647 & $0.024^{\star}$ \\
\hline Milk & 0.696 & 0.213 & 2.268 & 0.547 & 0.380 & 0.069 & 2.079 & 0.264 \\
\hline $\begin{array}{c}\text { Animal protein } \\
\text { (Eggs and red meat) }\end{array}$ & 6.840 & 1.601 & 29.223 & $0.009 *$ & 6.900 & 1.085 & 13.862 & $0.041 *$ \\
\hline Chips & 2.214 & 0.881 & 5.567 & 0.091 & 5.049 & 2.342 & 12.700 & $0.012^{\star}$ \\
\hline Sugars & 0.620 & 0.260 & 1.479 & 0.281 & 2.068 & 1.009 & 4.547 & $0.011^{*}$ \\
\hline $\begin{array}{l}\text { Preference of fatty } \\
\text { foods }\end{array}$ & 0.744 & 0.253 & 2.191 & 0.592 & 2.310 & 0.064 & 5.324 & 0.647 \\
\hline $\begin{array}{c}\text { Consumption of fast } \\
\text { foods }\end{array}$ & 4.461 & 3.057 & 19.884 & $0.005^{\star}$ & 3.029 & 1.001 & 12.639 & $0.025^{\star}$ \\
\hline $\begin{array}{c}\text { Sugar sweetened } \\
\text { beverages }\end{array}$ & 2.230 & 1.084 & 8.627 & $0.004^{*}$ & 0.038 & 0.003 & 1.556 & 0.117 \\
\hline Drinking water & 0.494 & 0.082 & 2.988 & 0.422 & 3.064 & 0.159 & 18.873 & 0.458 \\
\hline Physical in-activity & 5.183 & 1.731 & 13.265 & $0.002^{*}$ & 3.934 & 0.698 & 11.673 & 0.073 \\
\hline $\begin{array}{c}\text { Absence of Childhood } \\
\text { obesity }\end{array}$ & 0.160 & 0.027 & 0.941 & $0.043^{\star}$ & 0.036 & 0.002 & 0.667 & $0.026^{*}$ \\
\hline $\begin{array}{c}\text { Absence of family's } \\
\text { obesity }\end{array}$ & 0.238 & 0.064 & 0.883 & $0.032^{*}$ & 0.005 & 0.002 & 0.206 & $0.009 *$ \\
\hline Constant & 0.353 & & & $0.023^{\star}$ & 8.030 & & & $0.011^{*}$ \\
\hline
\end{tabular}

\section{Discussion}

Obesity class I and II were most common at age group less than 35 while co-morbid obesity was most common at old ages. This indicator for increasing obesity prevalence is in line with increasing the age and reaches its highest levels in the more than 35-yearold age group. This could be attributed to decreasing physical activity with increasing age. If, for example, this resulted in a body weight increase by only $1 \mathrm{~kg}$ per year, the weight would increase by $10 \mathrm{~kg}$ at the end of 10 years [11].

There is no doubt about the inverse relationship existing between physical activity and obesity [12-16], and the benefit and its preventive effect by acting on the control of fats and cholesterol $[17,18]$.

Results of the study linked being not married (single, divorced and widowed) with a lower percentage of chronic disease in women. On the other hand, married women were positively associated with chronic disease. It has been suggested that, after getting married, subjects are less physically active, change their dietary pattern, may be less focused on being attractive, have more social support, or may be exposed to other environmental factors [19].

Frequent consumption of fruits and its juices were classified as a protective factor among the participants. Reports indicated that increased fruit consumption contributed to reduced adiposity among obese and comorbid obese women. This result was consistent with other studies of overweight adults showed marked associations between increased consumption of fruits and vegetables and slower weight gain [20]. The mechanism by which fruit intake may prevent obesity is not fully understood but could be related to the clustering effect of healthy habits while other authors reported their fiber content and its effect on satiety and manage their body weight $[20,21]$.

In Palestine, as well as other countries in the Eastern Mediterranean region, the food habits and pattern of food consumption have changed enormously over the past decades [22]. The intake of fruit and vegetables and complex carbohydrates has 
decreased, which linked strongly with obesity prevalence. In addition, Western caloriedense fast foods are increasingly available and consumed by the young generation in this region [22-25].

The consumption of white meat like chicken has been related to the lower risk of obesity. Consistent with previous findings, adequate consumption of poultry meat can facilitate the control of body weight due to its high protein content and help to counteract against the development of obesity, cardiovascular diseases, diabetes mellitus and cancer [26]. On the other side, red meat can be relatively high in fats. It can also be energy dense and has a role in weight gain, overweight, and obesity. Eating more plants, especially vegetables and fresh fruit, in place of things like meats specially processed is said to be one of the most valuable things we can do to treat obesity and help reverse the growing obesity epidemic [27].

In addition, women who consumed more nuts are at risk of obesity, which opposes the previous studies of Flores-Mateo et al., Ibarrola-Jurado et al. in 2013 and Sabaté in 2003 [27-29]. Traditional weight loss diets tend to be low in total fat and therefore often restrict nut consumption. However, nuts are an important source of many vitamins, minerals, monounsaturated and polyunsaturated fatty acids. Studies showed that the role of nut consumption in body weight management is varied. Nuts, when included as part of an energy-controlled diet, were found to assist with weight management [30]. However, when nuts were added to an existing diet without controlling for energy intake, body weight increased, although to a lesser extent than theoretically predicted. There are limited evidence on the effect of nut consumption on non-communicable diseases, although available evidence indicates that nuts as part of a healthy diet do not cause weight gain and can have a positive influence on the fatty acid profile of a person with diabetes [30].

A positive correlation between fast food consumption and women obesity and chronic diseases was a significant finding, which is consistent and matched with other previous studies [31-35].

Possible factors determining obesity in the Eastern Mediterranean Region (EMR) including Palestine were nutrition transition, inactivity, urbanization, marital status, a shorter duration of breastfeeding, frequent snacking, skipping breakfast, a high intake of sugary beverages, an increase in the incidence of eating outside the home, long periods of time spent viewing television, massive marketing promotion of high fat foods, stunting, perceived body image, cultural elements, and food subsidize policy and A national plan of action to overcome obesity is urgently needed to reduce the economic and health burden of obesity in this region [36].

Physical activity (PA) provides important health benefits and recent guidelines on recommendation indicated that people should engage in light to moderate activity every day [37]. The study showed physical inactivity constitutes a risk factor that increased the prevalence of obesity and co-morbidity among the participants. Regular physical activity is associated with a healthier, longer life while inactivity is widely recognized as a major risk factor for chronic diseases [37,38].

Furthermore, the absence of childhood obesity and family history have reduced the risk of adulthood obesity and co-morbidity and reduced the risk of chronic diseases in the future. Genetics alone cannot explain obesity, gene-environment interaction can explain the high incidence of obesity [39]. Reports suggest that environmental factors are largely associated with the development of an obesity status and it also concludes that genetics only contributes $30 \%$ to the issue and $70 \%$ is attributed to the environment [40]. There has been a rise in unhealthy food accessibility along with long physical activity levels which are factors related to the genetic aspect of obesity [41]. 
Moreover, increase consumption of sugar-sweetened beverages increased the risk of obesity and co-morbid obesity among the participants. Worldwide, the consumption of sugar-sweetened beverages has increased dramatically in the past decades, in parallel with the increasing prevalence of overweight and obesity in the globally. Currently, sugary soft drinks contribute $\approx 8 \%-9 \%$ of total energy intake in both children and adults $[42,43]$. The calories provided by sugar-sweetened beverages have little nutritional value and may not provide the same feeling of fullness that solid food provides, so a total energy intake may increase which can lead to unhealthy weight gain [44].

\section{Conclusion}

This study was conducted to identify the possible risk factors contributing to obesity and co-morbid obesity among women aged $>25$ years in Gaza city, Palestine. Food and eating habits, physical activity, social characteristics, the relationship between parents' characteristics and BMI, family history of the disease and co-morbid obesity in parents were all examined. Logistic regression analysis predicted the dietary and lifestyle risk factors that contribute to the development of obesity class I and II /co-morbid obesity and chronic disease state among them. If the women more frequently eat legumes, nuts, eggs, fast food, and soda drink and if they less frequently engaged in a physical activity they are at risk. In contrast, lower intakes of meats and fruits were also the risk factors linked to the increased risk of morbid and co-morbid obesity. By the same way, absence of obesity during childhood and absence of family's history of obesity were protective factors.

Dietary risk factors that associated with the development of chronic disease included increase consumption of legumes, eggs, chips, sugar, and fast food while lower consumption of meat and absence of childhood obesity were considered as protective factors of chronic diseases. Based on the BMI measurements drawn from the sample of 116 obese women, $80.2 \%$ were classified as obesity class I and II and $19.8 \%$ were classified as co-morbid obesity. According to the study results, only $19 \%$ of the sample were classified as obese women with chronic disease. A national plan of action to overcome obesity is urgently needed to reduce its economic and health burden.

\section{References}

1. Gonçalves JT, Silveira MF, Campos MC, Costa LH. Overweight and obesity and factors associated with menopause. Ciencia \& saude coletiva. 2016; 21: 1145-1156. Ref.: https://goo.gl/SWb4VB

2. Hassan NE, Wahba SA, El-Masry SA, Elhamid ER, Boseila SA, et al. Eating Habits and Lifestyles among a Sample of Obese Working Egyptian Women. Open Access Maced J Med Sci. 2015; 3: 12 17. Ref.: https://goo.gl/hm8Dxf

3. Popkin BM. The nutrition transition and obesity in the developing world. J Nutr. 2001; 131: 871S-873S Ref.: https://goo.gl/8msHxs

4. Eckel RH, York DA, Rössner S, Hubbard V, Caterson I, et al. prevention conference VII. Obesity, a worldwide epidemic related to heart disease and stroke: executive summary. Circulation. 2004; 110 : 2968-2975. Ref.: https://goo.gl/kRAZJ2

5. Hill JO, Peters JC. Environmental contributions to the obesity epidemic. Science. 1998; 280: 13711374. Ref.: https://goo.gl/kRAZJ2

6. Popkin BM, Doak CM. The obesity epidemic is a worldwide phenomenon. Nutrition reviews. 1998; 56 : 106-114. Ref.: https://goo.gl/tCvevJ

7. Giles-Corti B, Macintyre S, Clarkson JP, Pikora T, Donovan RJ. Environmental and lifestyle factors associated with overweight and obesity in Perth, Australia. Am J Health Promot. 2003; 18: 93-102. Ref.: https://goo.gl/SXHUU7

8. Kanoa BJ, Abu-Nada OS, El-Sakka MA. Weight Reduction Perception and Practice among Female Students in Al-Azhar University-Gaza, Palestine. Turkish Journal of Public Health. 2008; 6: 47. Ref.: https://goo.gl/ECT43j

9. Merchant AT, Dehghan M, Behnke-Cook D, Anand SS. Diet, physical activity, and adiposity in 
children in poor and rich neighbourhoods: a cross-sectional comparison. Nutr J. 2007; 6: 1. Ref.: https://goo.gl/fKP6xy

10. Rodríguez-Martín A, Novalbos Ruiz JP, Martínez Nieto JM, Escobar Jiménez L. Life-style factors associated with overweight and obesity among Spanish adults. Nutr Hosp. 2009; 24: 144-151. Ref.: https://goo.gl/NJbpZC

11. Abrantes MM, Lamounier JA, Colosimo EA. Overweight and obesity prevalence in Northeast and Southeast Regions of Brazil. Rev Assoc Med Bras. 2003; 49: 162-166. Ref.: https://goo.gl/A69U7q

12. Prentice AM, Jebb SA. Fast foods, energy density and obesity: a possible mechanistic link. Obes Rev. 2003; 4: 187-194. Ref.: https://goo.gl/aMfSXi

13. Koh-Banerjee P, Chu NF, Spiegelman D, Rosner B, Colditz G, et al. Prospective study of the association of changes in dietary intake, physical activity, alcohol consumption, and smoking with 9-y gain in waist circumference among 16587 US men. Am J Clin Nutr. 2003; 78: 719-727. Ref.: https://goo.gl/8j6xjR

14. Gutiérrez-Fisac JL, Banegas Banegas JR, Artalejo FR, Regidor E. Increasing prevalence of overweight and obesity among Spanish adults, 1987-1997. Int J Obes Relat Metab Disord. 2000; 24: 1677. Ref.: https://goo.gl/aCsFUq

15. Rodríguez Artalejo F, López García E, Gutiérrez-Fisac JL, Banegas Banegas JR, Lafuente Urdinguio PJ, et al. Changes in the prevalence of overweight and obesity and their risk factors in Spain, 19871997. Prev Med. 2002; 34: 72-81. Ref.: https://goo.gl/P5TtsM

16. Petersen L, Schnohr P, Sørensen TI. Longitudinal study of the long-term relation between physical activity and obesity in adults. Int J Obes Relat Metab Disord. 2004; 28: 105. Ref.: https://goo.gl/CN7Bk2

17. Katzmarzyk PT, Janssen I, Ardern Cl. Physical inactivity, excess adiposity and premature mortality. Obesity reviews. 2003; 4: 257-290. Ref.: https://goo.gl/eW8vPP

18. Akbartabartoori M, Lean ME, Hankey CR. The associations between current recommendation for physical activity and cardiovascular risks associated with obesity. Eur J Clin Nutr. 2008; 62: 1. Ref.: https://goo.gl/JGHEor

19. WHO. Global strategy on diet, physical activity and health. 2004; Ref.: https://goo.gl/W2thzP

20. Tohill BC. Dietary intake of fruit and vegetables and management of body weight. 2005; WHO. Ref.: https://goo.gl/oCJxqH

21. Ledoux TA, Hingle MD, Baranowski T. Relationship of fruit and vegetable intake with adiposity: a systematic review. Obes Rev. 2011; 12: Ref.: https://goo.gl/iogKKA

22. Abudayya AH, Stigum H, Shi Z, Abed $Y$, Holmboe-Ottesen G. Sociodemographic correlates of food habits among school adolescents (12-15 year) in North Gaza Strip. BMC Public Health. 2009; 9: 185 Ref.: https://goo.gl/y5TaLr

23. Musaiger A. Food consumption patterns in the Eastern Mediterranean Region. Food consumption patterns in the Eastern Mediterranean Region. 2011; Ref.: https://goo.gl/NE2RGP

24. Niemeier HM, Raynor HA, Lloyd-Richardson EE, Rogers ML, Wing RR. Fast food consumption and breakfast skipping: predictors of weight gain from adolescence to adulthood in a nationally representative sample. J Adolesc Health. 2006; 39: 842-849. Ref.: https://goo.gl/n6h1T7

25. Shan $X Y, X i B$, Cheng $H$, Hou DQ, Wang $Y$, et al. Prevalence and behavioral risk factors of overweight and obesity among children aged 2-18 in Beijing, China. Int J Pediatr Obes. 2010; 5: 383-389. Ref.: https://goo.gl/qJocoQ

26. Donma MM, Donma O. Beneficial Effects of Poultry Meat Consumption on Cardiovascular Health and the Prevention of Childhood Obesity. Med One. 2017; Ref.: https://goo.gl/p694QP

27. Ibarrola-Jurado N1, Bulló M, Guasch-Ferré M, Ros E, Martínez-González MA, et al. Cross-sectional assessment of nut consumption and obesity, metabolic syndrome and other cardiometabolic risk factors: the PREDIMED study. PloS one. 2013; 8: e57367. Ref.: https://goo.gl/msZRG2

28. Flores-Mateo G1, Rojas-Rueda D, Basora J, Ros E, Salas-Salvadó J. Nut intake and adiposity: metaanalysis of clinical trials-. The Am J Clin Nutr. 2013: 97: 1346-1355. Ref.: https://goo.gl/w6JCD8

29. Sabaté J. Nut consumption and body weight. Am J Clin Nutr. 2003; 78: 647S-650S. Ref.: https://goo.gl/eiNfny

30. Natoli S, McCoy P. A review of the evidence: nuts and body weight. Asia Pac J Clin Nutr. 2007; 16: 588-597. Ref.: https://goo.gl/SzXzqX 
31. Mihrete K. Association between fast food consumption and obesity and high blood pressure among office workers. 2011; Walden University. Ref.: https://goo.gl/sFGYSR

32. Al-Haifi AR, Al-Fayez MA, Al-Athari BI, Al-Ajmi FA, Allafi AR, et al. Relative contribution of physical activity, sedentary behaviors, and dietary habits to the prevalence of obesity among Kuwaiti adolescents. Food Nutr Bull. 2013; 34: 6-13. Ref.: https://goo.gl/j5obBW

33. Washi SA, Ageib MB. Poor diet quality and food habits are related to impaired nutritional status in 13-to 18-year-old adolescents in Jeddah. Nutr Res. 2010; 30: 527-534. Ref.: https://goo.gl/5VGtd7

34. Andreyeva T, Kelly IR, Harris JL. Exposure to food advertising on television: associations with children's fast food and soft drink consumption and obesity. Econ Hum Biol. 2011; 9: 221-233. Ref.: https://goo.gl/V13tnv

35. Fraser LK, Edwards KL, Cade JE, Clarke GP. Fast food, other food choices and body mass index in teenagers in the United Kingdom (ALSPAC): a structural equation modelling approach. Int J Obes (Lond). 2011; 35: 1325. Ref.: https://goo.gl/omq7BW

36. Musaiger AO. Overweight and obesity in eastern mediterranean region: prevalence and possible causes. Journal of obesity. 2011; 2011: Article ID 407237. Ref.: https://goo.gl/9XpRCL

37. Viuda-Serrano A, González-Millán C, Pérez-González B. Obesity Prevention through Physical Activity in School-Age Children and Adolescents. 2010, Retrieved 29/04/2012. Ref.: https://goo.gl/3DEpU1

38. Martins ADS/ Atividade física, autoavaliação negativa de saúde e condutas de risco em adolescentes. 2017; Ref.: https://goo.gl/xkyurC

39. Ellulu MS, Jalambo MO. Gene-environment interaction: The causes of high obesity incidence. Kathmandu Univ Med J. 2017; 57: 90-92. Ref.: https://goo.gl/tYzEZb

40. Stevenson N. Family Environmental Characteristics Associated with Obesity in African American High School Girls. 2008; Ref.: https://goo.gl/ccdB9n

41. Elinder LS, Jansson M. Obesogenic enviromentsaspects on measurement and indicators. Public Health Nutrition. 2008; 12: 307-315. Ref.: https://goo.gl/S9cmXT

42. Nielsen SJ, Popkin BM. Changes in beverage intake between 1977 and 2001. Am J Prev Med. 2004 27: 205-210. Ref.: https://goo.gl/F6Vv2z

43. Bray GA. Soft drink consumption and obesity: it is all about fructose. Curr Opin Lipidol. 2010; $21: 51$ 57. Ref.: https://goo.gl/hgvyBb

44. WHO. Reducing consumption of sugar-sweetened beverages to reduce the risk of childhood overweight and obesity. 2015; Ref.: https://goo.gl/rBDYUa 